\title{
WALL MAGAZINE AS MEDIA IN GRASPING PUPILS' READING INTEREST AT PRIMARY LEVEL
}

\author{
Diah Astuty ${ }^{1)}$, Fathurrahman ${ }^{2)}$ \\ Lamongan Islamic University \\ diahastuty@unisla.ac.id ${ }^{1}$, fath@unisla.ac.id ${ }^{2)}$
}

\begin{abstract}
The paper aims to describe the literacy movement initiated by Indonesian Government. Since there is disproportional distribution of literacy exposures between the pupils who are living in urban areas and the pupils who are living in rural areas, it needs important roles of teachers and school managements mainly for those at rural areas in developing and improving reading habits for their pupils. The wall magazines can be used as affordable media in grasping pupils' reading interest at primary level. The appropriate procedures in using wall magazines at primary schools can support divergent purposes to make the pupils get interested in reading. The use of wall magazines is also intended to create reading environment for the pupils in order to learn and apply the literacy movement program at early level. The appropriate use of strategies in using wall magazine is planned to train the pupils learning how to read and think critically about the textual materials that are provided by using attractive and appropriate visual mode. The study would be conducted as casestudy in describing the procedures and the use of wall magazine at SDN Pamolokan 3 at Sumenep as a part of Literacy Movement program at school (which known as Gerakan Literasi Sekolah or GLS). The data of this study would be qualitative data in the forms of questionnaires results and interviews.
\end{abstract}

Keywords: Literacy Exposures, Wall Magazine, Literacy Movement, Literacy Competence

\section{INTRODUCTION}

Since UNDP issued the Indonesian Human Development Index in 2016 that it was considerably low at the point of 0.689 , this fact consequently places Indonesia as the $113^{\text {th }}$ of 188 countries around the world. The information has given real description that one factor of other accumulated determining factors of the HDI in Indonesia; in relation to the inequality for achieving descent standard living was the inequality of literacy competence. The Indonesian government relates the inequality for achieving descent standard living with literacy competence from Indonesian citizens concerning of their literacy competence. This was an urgent issue and needed to develop from time to time into the government strategic plans. The national program on literacy movement was initiated on the UNDP overview that the literacy competence would open access to knowledge.

Meanwhile, there is unequally proportion of literacy competence distribution from Indonesian pupils because of factor of their domicile areas. The pupils who living in Java, Sumatra and the pupils who living in some remote areas at Papua would gain differently in their literacy competence because of the difference in literacy exposure to the pupils. Similarly, the condition of the disproportional exposure to literacy competence among Indonesian pupils also occurs between those who are living in urban areas and those who are living in rural areas. The Indonesian pupils who 
living in urban areas is more widely exposed to develop their literacy competence than the other pupils in rural areas consequently from several reasons lying behind. The condition has been supported by the level of education from the parents since the higher level of education from the parents will provide wider access to the children improving their literacy competence (Pakpahan, 2016: 339). Furthermore, the children who are living in urban areas get more facilities since the better facilities are provided by regional government or private sectors. There are many reading parks provided for children who live at urban areas can utilize. The public areas such as public libraries or private libraries, book stores are the facilities that the children can occupy.

In addition to the formerly discussed condition, the lack of interest from Indonesian pupils on their reading habit could be triggered by the culture in which almost Indonesian families consider reading habit is not a part of their primary needs. Reading is considered as the activities that it must be involved with academic activities; therefore, reading is a part of schools or formal/informal learning places responsibility to their pupils or learner communities. By adopting the misleading assumptions, there are numbers of Indonesian parents assume that reading is not a part of their family culture or responsibilities of parents to their family members. Consequently, the parents' roles to contribute on their children's reading activities considerably less than the children need to have.

Therefore, schools and learning communities are accessible facilities to provide the children for improving their literacy competence. Principally, schools as formal learning institutions for children have responsibility to deal with this competence. Schools which function as the primary sources of knowledge for the pupils who living in rural areas should play important roles with the purpose of attracting the pupils' interest mainly in reading activities. There are some programs supporting Literacy Movement program that the schools and learning communities need to implement and be considered.

As a result, teachers and school management should work cooperatively in creating innovative and attractive media for the pupils in order to develop their reading habit. This study would describe the use of wall magazines at SDN Pamolokan 3 Sumenep that facilitate it as the media for running the program which called Gerakan Literasi Sekolah (GLS) or the Literacy Movement program at school.

\section{RESEARCH METHOD}

This study would apply case study to describe the use of wall magazines as the media that it would facilitate the reading activities for the pupils at SDN Pamolokan 3 Sumenep. The media of wall magazine would be functioned as the supporting media in promoting literacy movement program at school or Gerakan Literasi Sekolah (GLS).

The qualitative data would be resulted from the interview and questionnaires that distributed to the teachers of SDN Pamolokan 3 Sumenep who teaching at $4^{\text {th }}$ grade to $6^{\text {th }}$ grade. The wall magazines considered would be effective to apply for the pupils at $4^{\text {th }}$ grade above. There were three factors that the study would emphasize to explore in using the wall magazines as media; (1) the use of wall magazines in building sense of 
belonging and responsibility from the pupils, (2) the use of wall magazines as a strategy to attract the pupils' interest in reading and (3) the use of wall magazines with the collaborative reading method.

\section{Facilitating Reading Environment for Pupils at Primary Level}

Reading for pupils at primary level should be triggered with several motivations. Motivations to read should be created by the environment where the pupils get involved with. The environment could be the family environment where the pupils are brought up and the school where the pupils are learning.

Slameto (in Pakpahan, 2016) stated that there are internal factors and external factors influence the pupils in learning. External factors for instance the school environment could be created in order to give learning atmosphere for the pupils. The school environment include teachers are the part of motivation triggers for the pupils to construct their reading habit.

Therefore, facilitating reading environment for pupils living at rural region could be conducted by involving the essential roles of teachers in addition to motivate their pupils' reading habit. Teachers as facilitators are considered as the key in creating reading habit. The atmosphere that teachers create can generate the interest of pupils to read. According to Wortham (2006: 330), teachers should acquire ability to implement reading comprehension strategies to enhance their pupils' understanding and enjoyment of what the pupils read. Teachers should act as assessor and evaluator in keeping of track to their pupils' reading activities that the reading activities need to observe with the intention of developing the pupils' reading competence.

The role of environment is important for promoting literacy to the pupils. Reading environment at elementary school should provide opportunities for the pupils to explore, to experiment, to hypothesize and to reflect about what the pupils have read. It would recommend creating classroom that is enriched with printed materials. The print rich environment that consists of books, children's material readings and environmental prints such as flyers, manuals and letters could encourage the pupils to develop their reading competence (Tankersley, 2003: 162).

At SDN Pamolokan 3 Sumenep, the school management facilitated the reading environment by providing the reading corner that it provided some books to the pupils. Wall magazines were provided in each classroom to support reading activities conducted by the pupils. The school management also allocated extra 30 minutes before the classes began twice in a week. The extra allocation time was aimed to habituate the pupils' reading activities.

\section{The procedures of collaborative reading with wall magazines as the media}

When the pupils are triggered their reading interests, the pupils can enjoy their reading activities in more pleasures and enjoyment. Although their reading activities are considered situational activities since the activities are triggered externally for instances because of some attractive books provided, teachers are considered to create more motivating activities in order to inject more intrinsic motivation to their pupils for developing their reading habit. Teachers can 
implement apt approaches and strategies to stimulate their pupils starting their reading activity and developing their pupils' reading interest for exploring more about the reading materials. The concept of this reading activity is enduring.

Enduring concept needs the teachers play more than as the model of successful readers to their pupils (Cambria, 2010: 17). By doing this, it hopefully encourages the pupils to get more motivated internally and the pupils have awareness that reading is a part of life activities. The pupils can appreciate more respectfully the value of their reading activities. The pupils can gain more confidence that their reading ability is being improved time to time. Further, the pupils can relate their experiences in reading with their daily experiences.

Collaborative reading activities in enduring concept are recommended since the activities can encourage the pupils to learn how to gain success by collaboration. The pupils need to learn how to socialize and assess them as individual with the others in one group relating to improving their personal reading performance. The activities can motivate the pupils to improve their reading performance by learning aspects of their reading performance in which they can select or analyze the aspects from themselves that need to improve. The pupils can reflect what they've read, discuss and respond to book or other materials. In addition, the pupils can learn how to manage the diversity among them in classroom by encouraging varied thinking and extending understanding of reading materials in socio-cultural context (Pittman, 2014: 119).

Additionally, the procedure of collaborative reading activities at this study would be focused on the reading activities of the pupils at $4^{\text {th }}$ grade class to the pupils at $6^{\text {th }}$ grade class. The classroom teachers distributed the pupils into small groups that it consisted of 5 to 6 pupils each. The strategies for reading activities could diverge starting from independent reading activities, practicing storytelling and making resume of the reading materials.

Wall magazines would be used as media to display the groups' resumes and synopsis of the reading materials. Teachers would introduce the use of wall magazine as display media by asking each group displayed their basic literacy product such as synopsis. Other group could read the other group's basic literacy product displayed on the wall magazines.

\section{Using Wall Magazine as Media to Attract Pupils' Interest to Read}

School managements need to consider the ways creating reading environment to their elementary pupils by utilizing wall magazines. Besides good management of school library, school management and teachers should creatively occupy any spaces of the school to become media for literacy movement.

Likewise, school managements and teachers could use corridors and classroom's spaces as reading environment to encourage the pupils' reading habits by using wall magazines. Wall magazines should be managed creatively and carefully. The appropriate procedures using wall magazines should be concerned by school management and teachers in purpose of attracting the pupils' interest to read the wall magazines. Mostly, the pupils are more interested in the visual mode of the text. At primary level, the pupils are found to tend to learn the conceptual of re- 
organization of the world through images (Dimopoulos, 2003: 3271).

Regarding the formerly reasons, each classroom is recommended to construct its own wall magazines on the subject of educating or triggering the pupils' literacy. There are some deferentially purposes to do this activity. First, by having each own wall magazines, the pupils are encouraged to acquire sense of belonging at early stage of their life. Having sense of belonging would promote the responsibility to the pupils.

The second purpose is teachers at each level can creatively create the content of wall magazines based on the level of reading competence. They can select the content to promote their pupils' both reading needs and reading interests.

The third purpose is teachers could collaborate with their pupils in creating their wall magazines. This activity can encourage the close relationship between teacher and pupils with emotional bounds. The teacher could observe and do assessment in understanding the needs of their pupils and the pupils' problem in reading.

The procedures in using wall magazines should rely on several considerable factors. The first is the place where the wall magazines should be hung on or put. There should be centers for wall magazines with specific contents that the pupils can easily catch up and read. The most important is the pupils should be trained how and where they can find out and read specific information which they are looking for.

The second procedure is the layout of wall magazines. Ideally, the wall magazine should be eye-catchy in order to attract the pupils' attention and then, trigger their interest to read. The language should be easily understood for children in purpose of generating their confidence to read and valuing their reading competence. The content should be selected carefully by school management and teachers to avoid unnecessary and inappropriate content for children to read. The content of the text for wall magazines should be interesting in its visual mode since the pupils were observed being triggered their reading interest by visual stimulus such as a play object or viewing a picture (Hidi, 2001: 192).

The third procedure is the selection of the text material content for the wall magazine. Relating to the purpose of using wall magazine in attracting the pupil's reading interest, teachers and school management should consider the ways how to select the good content of text material. Teachers need to consider how to apply authentic practices that the practices can be connected to broader social and cultural practices within their local communities and the pupils' communities (Larson, 2005: 24). Pupils need to be asked in taking participation to understand or formulate the purposes for the activities of their reading.

This study would describe the interconnection of using wall magazines as reading media that it could deliver positive effects to the pupils such as the sense of belonging and sense of having responsibility. Using wall magazines would enhance the pupils' interest in reading increase.

\section{FINDING AND DISCUSSION}

The findings showed that teachers used wall magazines as media to support literacy movement program (Gerakan Literasi Sekolah) at SDN Pamolokan 3 Sumenep. Teachers used wall magazines as media to locate reading materials at 
each classroom. Each wall magazine has different theme for each classroom since the wall magazines were applied with various reading materials to support literacy movement program.

The material contents for wall magazines were teachers' decision. Teachers selected the reading contents based on three criteria: (1) the reading contents were selected in accordance with the age and the grade of the pupils, (2) the reading contents were selected to function as learning sources for the pupils and (3) the reading contents were selected to correspond with the pupils' reading competence. Teachers as the only decision makers in selecting the material contents for wall magazines since teachers considered the pupils' selecting material content capacity which had not been integrated to meet the three criteria formerly mentioned. The independency was given to the pupils in accordance with their interest picking up the appropriate reading materials which were displayed on the wall magazines during literacy movement program.

The social attitude assessments in relation to the use of wall magazines in the classroom were conducted to observe the pupils' sense of belonging and their responsibility on the wall magazines property. Teachers reported that the pupils would give some reports on any inappropriate condition happened to the wall magazines. Some teachers also reported that some students would make voluntarily actions in repairing small and flip damages on the wall magazine's properties under teachers' guidance. Teachers reported that the older pupils have been aware the importance of having and keeping the wall magazine as their learning sources at their each classroom.
The use of wall magazines has been conveyed the increase of the pupils' reading interest. Teachers reported that during the conduct of literacy movement program at school (Gerakan Literasi Sekolah), the pupils conducted their independently reading activities automatically. The indicator of this increasing interest from the pupils in spending their reading activities reported that the pupils conducted their reading activities without the interference of teachers. The pupils selected any reading materials by themselves and consumed their reading allocated time. After that, the pupils conducted their each literacy journal. The pupils would write any resumes and synopsis of the stories that they have read. They would hang their literacy product to be displayed on the wall magazines.

The use of wall magazines as the media would be combined with collaborative reading strategies. Teachers reported that they implemented the practice of storytelling strategy in a group. Each group would make resume and synopsis for their literacy journal. The literacy product would be displayed on the classroom's wall magazines. Teachers reported that this strategy was effective to combine with the use of wall magazines.

\section{CONCLUSION AND SUGGESTION}

The study conducted to deliver conclusions as follows:

1. The use of wall magazines as the reading media conducted at SDN Pamolokan 3 Sumenep considered successfully in creating reading environment with the purpose to trigger the pupils' reading habit. The selection of reading materials displayed on the wall magazines was 
conducted carefully based on three criteria that (1) reading materials displayed would correspond with the pupils' age and grade, (2) reading materials would fit with the reading competence of the pupils and (3) reading materials displayed could be functioned as learning sources. The stimulus of the implementation has been reported positively. The pupils would consume their provided allocation time in reading activities independently without the interference of teachers. Teachers reported through their observation about the pupils' reading activities that the pupils endured their reading activities and increased their literacy competence by conducting their literacy journal. The product of the pupils' literacy would be displayed on each classroom's wall magazines.

2. The use of wall magazine in each classroom could be used as a parameter to observe the social attitude of the pupils. Teachers reported that the pupils attained the sense of belonging and the sense of responsibility in keeping the property which was useful as their learning media. The pupils would make any reports about the inappropriate condition of wall magazine and some would voluntarily fix the small and flip damage under teachers' guidance.

3. The use of wall magazine could be effective media that it was applied with collaborative reading activities. The wall magazine would be a media display for other group's synopsis or resumes of the story that the pupils discussed in a group. The literacy product of other group could motivate other group to produce equally literacy product.

The study also recommended some suggestions as follows:

1. It would be recommended that the process of design, layout of the wall magazines to the process of reading material selection conducted collaboratively between teachers and pupils. These activities could be useful for teachers in doing observation about their pupils' reading competence, the pupils' creativity and the pupils' social attitudes.

2. It would be recommended that the selection criteria on the reading materials also include thematic reading materials. This could enhance the pupils' confidence in reading competence.

\section{REFERENCES}

Bell, Stephanie. (2010). Project Based Learning for the $21^{\text {st }}$ Century: Skills for Future. The Clearing House 83 pp. 39-43. Routledge Taylor \& Francis Group. ISSN: 0009-8655. DOI:

10.10180/00098650903505415.

Bolak. Karen \& et.al. (2005). Standards Based, Thematic Units Integrate the Arts and Energize Students and Teachers. Middle School Journal. Retrieved from: https://www.nmsa.org.

Dimopoulos, Costas \& Koulaidis, Vasilis. (2003). An Analysis of the Discursive Transitions across Different Modalities of the Pedagogic Discourse. International Journal of Learning Vol. 10. Australia: Common Ground Publishing Pty Ltd. 
Hidi, Suzanne. (2001). Interest, Reading and Learning: Theoretical and Practical Considerations. Educational Psychology Review Vol. 13 No. 3.

Larson, Joanne \& Marsh, Jackie. (2005). Making Literacy Real: Theories and Practices for Learning and Teaching. London: SAGE Publication Ltd.

Meigs, Frau Divina. (2006). Media Education: A Kit for Teachers, Students, Parents and Professional. Paris: UNESCO.

Pakpahan, Rogers. (2016). Factors Affecting Literacy Mathematics Achievement of Indonesian Students in PISA 2012. Jurnal Pendidikan dan Kebudayaan, Vol.1, Nomer 3. Indonesia.

Pittman, Pamela \& Honchell, Barbara. (2014). Literature Discussion: Encouraging Reading Interest and Comprehension in Struggling Middle School Readers. Journal of Language and Literacy Education Vol. 10 Issue 2. Retrieved from:http://jolle.coe.uga.edu.
Suh, Heejeon. (2011). Collaborative Learning Models and Support Technologies in the Future Classroom. International Journal for Educational Media and Technology 20011 Vol. 5. No. 1, pp. 50-61. ISSN 1882-1693.

Tankersley, Karen. (2003). Threads of Reading: Strategies for Literacy Development. USA: Association of Supervision and Curriculum Development.

Wortham, Sue C. (2006). Early Childhood Curriculum. New Jersey: Pearson Education, Inc. 